\title{
Pembentukan dan Makna Gitaigo dalam Komik Handa Kun Karya Satsuki Yoshino
}

\author{
Ni Nyoman Ariesta Cakadha Meganing*, I Made Budiana, I Nyoman Rauh Artana \\ PS Sastra Jepang, FIB, Universitas Udayana, Bali, Indonesia \\ [ganing.ariesta@gmail.com], [budi.hybrid@gmail.com],[rauhartana@gmail.com]
}

\begin{abstract}
The title of this research is "Formation and Meaning on Gitaigo of Handa Kun Comic by Satsuki Yoshino" that aimed to explain the forming process and meaning on gitaigo of Handa Kun comic 1-7 volume by Satsuki Yoshino. The problem in this research was analyzed by using formal method and informal technique. Gitaigo formation analysis used Japanese morphology theory by Tsujimura (1996) and characteristic of Japanese onomatopoeia by Akimoto (2002). While the gitaigo meaning analysis used semantic property theory by Chaer (2015a). The result of this research is on Handa Kun comic was found three types of gitaigo formation i.e. reduplication, affixation, and compounding. Furthermore, the characteristic of onomatopoeia that found are hanpuku, sokuon, choo'on, hatsuon, and -ri morpheme addition. Then, inheritance elements and additional elements was found in each gitaigo. Through additional elements found, there is an expansion meaning or constriction meaning can be known in the words that formed by gitaigo.
\end{abstract}

Keywords: morphology, gitaigo, semantic property

\begin{abstract}
Abstrak
Penelitian ini berjudul "Pembentukan dan Makna Gitaigo dalam Komik Handa Kun Karya Satsuki Yoshino" adalah penelitian yang bertujuan untuk menjelaskan proses pembentukan serta makna gitaigo dalam komik Handa Kun jilid 1-7 karya Satsuki Yoshino. Masalah dalam penelitian ini dianalisis dengan menggunakan metode formal, dan teknik yang digunakan adalah teknik informal. Dalam analisis pembentukan gitaigo digunakan teori morfologi bahasa Jepang oleh Tsujimura (1996) dan teori karakteristik onomatope bahasa Jepang oleh Akimoto (2002). Sedangkan pada analisis makna gitaigo digunakan teori komponen makna oleh Chaer (2015a). Hasil penelitian ini menunjukkan bahwa dalam komik Handa Kun ditemukan tiga jenis pembentukan gitaigo, yaitu reduplikasi, afiksasi, dan komposisi. Selain itu, karakteristik gitaigo yang ditemukan adalah berbentuk hanpuku, sokuon, choo'on, hatsuon, dan penambahan morfem -ri. Kemudian pada tiap-tiap gitaigo ditemukan unsur makna turunan dan tambahan. Melalui unsur tambahan yang ditemukan, dapat diketahui pada kata-kata yang dibentuk dengan gitaigo terjadi perluasan atau penyempitan makna.
\end{abstract}

Kata kunci: morfologi, gitaigo, komponen makna 


\section{Latar Belakang}

Jepang merupakan negara yang kebudayaannya sudah dikenal secara global. Salah satunya adalah komik berbahasa Jepang atau yang sudah dikenal dengan istilah manga. Di dalam sebuah manga, terdapat kumpulan tulisan-tulisan unik yang biasanya ditulis dengan huruf katakana dan bercetak tebal. Tulisan-tulisan tersebut merupakan tiruan bunyi atau yang juga dikenal dengan istilah onomatope. Dalam bahasa Jepang, onomatope adalah giongo yang secara harfiah berarti "sebuah kata yang meniru bunyi," dan mimesis adalah gitaigo yang secara harfiah berarti "sebuah kata yang meniru tindakan atau keadaan" (Fukuda, 2017: vi). Adverbia yang menggambarkan bunyi atau suara disebut giongo/giseigo, sedangkan adverbia yang menyatakan suatu keadaan disebut gitaigo. Kedua istilah ini biasa disebut onomatope (Dahidi dan Sudjianto, 2004: 168). Dalam bahasa Jepang, onomatope juga merupakan unsur yang mengalami proses ulangan atau reduplikasi (Tsujimura, 1996: 152). Tidak hanya reduplikasi, onomatope dalam manga juga dibentuk dengan berbagai macam proses pembentukan kata. Seperti proses pemendekan, afiksasi, dan yang lainnya. Onomatope yang terbentuk melalui proses pembentukan kata dapat memiliki komponen makna turunan yang sama dan komponen makna tambahan yang berbeda-beda. Analisis komponen makna ini akan sangat membantu dalam memahami makna khusus dalam onomatope yang diterapkan dalam sebuah manga, baik yang berada di dalam dialog maupun di luar dialog.

Sebagai pembelajar bahasa Jepang, tidak hanya memahami struktur, tetapi juga penting untuk memahami pola makna dan gramatikal serta budaya yang terkandung dalam suatu bahasa. Banyak kata-kata menarik yang dapat diteliti lagi dari sisi komponen makna, proses pembetukan, serta asal-usulnya. Contohnya adalah onomatope berjenis gitaigo dalam bahasa Jepang. Gitaigo merupakan kategori onomatope bahasa Jepang yang cukup menarik untuk dipahami karena bukan hanya sekedar tiruan bunyi, namun juga menggambarkan keadaan dan situasi juga seringkali terbentuk sebagai berbagai macam kata turunan. Gitaigo dalam sebuah manga bukan hanya sekedar hiasan, karena dengan adanya gitaigo, situasi dan 
pergerakan yang terbatas dalam manga dapat diperjelas sehingga maksud dari penulis manga dapat tersampaikan dengan baik kepada pembaca. Selain giongo/giseigo, gitaigo juga merupakan salah satu unsur penting yang dapat menghidupkan sebuah manga. Oleh karena itu, memahami gitaigo melalui asalusul pembentukan serta berbagai makna yang dihasilkan adalah hal yang penting guna memperkaya pengetahuan dalam bidang kebahasaan. Beragamnya bentuk gitaigo dalam sebuah manga seringkali membuat pembelajar bahasa Jepang bingung memaknai gitaigo tersebut. Makna yang sebenarnya ingin ditunjukkan dapat bertambah atau berkurang didukung dengan konteks atau situasi yang digambarkan dalam sebuah komik. Oleh karena itu, memahami makna dan pembentukan gitaigo dalam manga akan memudahkan pembelajar dalam hal memahami penggunaan tiruan bunyi dengan tepat. Penelitian ini dikhususkan pada onomatope dalam kategori gitaigo, mengenai pembentukan yang disajikan dengan bagan pembentukan setahap maupun bertahap (Chaer, 2015b:28). Selain mengenai proses pembentukan, dibahas juga mengenai perubahan kelas kata yang diakibatkan melalui proses pembentukan tersebut. Pembentukan kata pada umumnya terdiri dari dua jenis, yaitu derivasi dan pemajemukan (Herman \& Ba'dulu, 2010:30). Pada penelitian ini, proses pembentukan mengakibatkan terjadinya derivasi maupun infleksi pada sebuah kata. Perubahan makna disajikan dengan penjabaran narasi berdasarkan unsur-unsur makna yang terdapat dalam sajian tabel komponen makna. Penelitian serupa sudah pernah dilakukan sebelumnya, diantaranya adalah penelitian dari Arisuta (2017), Erdika (2016), Firmanningrum (2016), dan Panduwinata (2013), namun dengan permasalahan serta sumber data yang berbeda.

\section{Pokok Permasalahan}

Sesuai dengan latar belakang yang telah dipaparkan di atas, masalah yang dibahas dalam penelitian ini dapat dirumuskan sebagai berikut.

a) Bagaimanakah pembentukan gitaigo dalam komik Handa kun karya Satsuki Yoshino?

b) Bagaimanakah makna gitaigo dalam komik Handa kun karya Satsuki Yoshino? 


\section{Tujuan Penelitian}

Tujuan penelitian ini dibedakan menjadi dua, yakni tujuan umum dan tujuan khusus. Secara umum penelitian ini bertujuan untuk memberikan informasi mengenai pembentukan dan makna gitaigo juga menambah kontribusi dalam kajian linguistik. Secara khusus penelitian ini bertujuan untuk mengetahui pembentukan dan makna gitaigo dalam komik Handa-kun karya Satsuki Yoshino tahun 20142016 volume 1-7 beserta versi terjemahan bahasa Indonesia tahun 2017 yang digunakan untuk membantu proses analisis.

\section{Metode Penelitian}

Data dari objek penelitian yaitu komik Handa Kun karya Satsuki Yoshino dikumpulkan dengan metode simak dan teknik catat oleh Sudaryanto (1993). Pembentukan gitaigo dianalisis dengan teori morfologi bahasa Jepang oleh Tsujimura (1996) dan Karakteristik onomatope bahasa Jepang oleh Akimoto (2002). Kemudian makna gitaigo dianalisis dengan teori Komponen Makna oleh Chaer (2015a). Dalam proses analisis data digunakan metode padan intralingual dan teknik hubung banding oleh Mahsun (2005). Hasil analisis data disajikan dengan metode formal dan teknik informal oleh Sudaryanto (1993) yaitu metode penyajian data berupa bagan dan tabel serta teknik analisis berupa narasi kalimat untuk menjelaskan data.

\section{Hasil dan Pembahasan}

\subsection{Pembentukan Gitaigo}

Dalam komik Handa kun karya Satsuki Yoshino, terdapat tiga jenis pembentukan gitaigo yang ditemukan yakni yang paling dasar adalah reduplikasi, kemudian ditemukan juga pembentukan afiksasi dan komposisi. 


\subsubsection{Gitaigo yang Bereduplikasi}

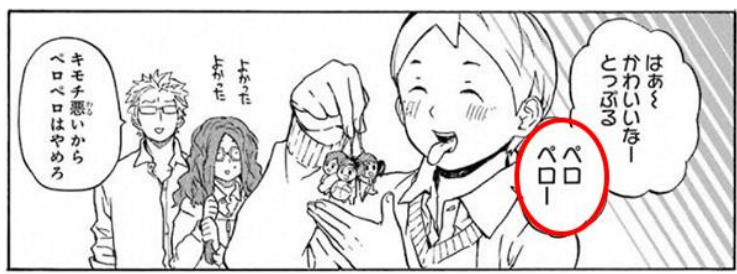

Gambar (1)

$\begin{array}{lll}\text { (1) はあー } & \text { かわいい } & \text { なー } \\ \text { Haaa } & \text { kawaii } & \text { naa } \\ \text { Aah } & \text { manis } & \text { SHU } \\ \text { とっぷる } & \text { ペロペロー } & \\ \text { toppuru } & \text { peroperoo } & \\ \text { triple } & \text { jilat-jilat } & \end{array}$

'Aah, triple yang manis, slerp slerp' [Handa kun, 78, 2015, Jilid 3]

Peropero berasal dari bentuk dasar pero yang juga merupakan morfem dasarnya. Data (1) menunjukkan gitaigo dasar pero memiliki bentuk sokuon atau pemadatan suara untuk menunjukkan pergerakan yang cepat atau sesaat. Sementara pada peropero terdapat karakteristik hatsuon atau pemanjangan vokal untuk memberi kesan aktivitas yang berlangsung lama. Pembentukan gitaigo pero menjadi peropero dapat dilihat dari proses berikut.

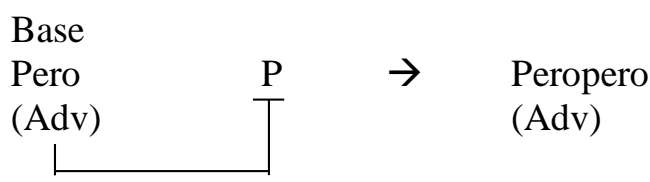

Morfem dasar $\{$ pero $\}$ dibentuk dengan proses pemajemukan morfem (reduplikasi) menjadi peropero. Proses tersebut menjelaskan bahwa reduplikasi morfem dasar $\{$ pero $\}$ menyebabkan terbentuknya gitaigo dengan karakteristik hanpukukei (bentuk morfem majemuk) yaitu peropero. Proses ini terjadi secara inflektif karena peropero tidak mengalami perubahan kelas kata dari morfem dasarnya, yaitu masih merupakan adverbia.

\subsubsection{Gitaigo yang Berafiksasi}

Afiksasi yang ditemukan dalam komik Handa Kun seluruhnya berupa sufiks. Sufiks-sufiks yang ditemukan ada lima macam, yakni sufiks -suru, -saseru, -tsuku, 
-tsukeru, dan -ri (dapat dilihat di skripsi halaman 50-56). Berikut merupakan penjelasan pembentukan gitaigo yang berafiksasi pada kata surari.

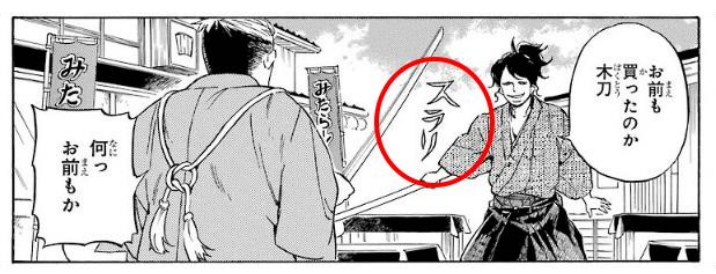

Gambar (2)

(2) スラリ

Surari

'Sret'

[Handa kun, 75, 2016, Jilid 5]

Surari merupakan sebuah gitaigo yang berafiksasi berupa penambahan sufiks ri. Surari berasal dari sebuah morfem akar $\{$ sura $\}$ dan terlihat memiliki sebuah karakteristik gitaigo berupa penambahan morfem -ri. Dalam onomatope bahasa Jepang, penambahan morfem -ri digunakan sebagai sufiks penanda pergerakan yang ringan, pelan dan halus. Untuk mengetahui pembentukan sura menjadi surari, dapat dilihat dari proses berikut.

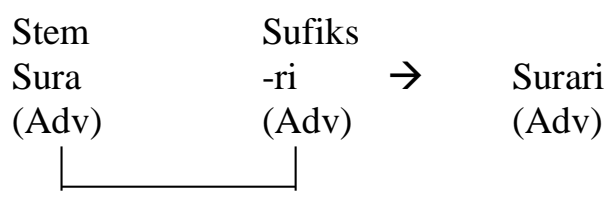

Proses tersebut menunjukkan pemberian imbuhan morfem sufiks $\{-r i\}$ pada pangkal sura yang juga merupakan morfem dasar. Morfem sufiks $\{-r i\}$ merupakan morfem berjenis adverbia yang hanya diimbuhkan pada onomatope bahasa Jepang. Dapat disimpulkan bahwa proses tersebut terjadi secara inflektif karena kelas kata antara pangkal kata dan morfem sufiks adalah sejenis sehingga tidak menimbulkan pergeseran kelas kata dan hasil akhir masih berupa adverbia yaitu gitaigo surari. 


\subsubsection{Gitaigo yang Berkomposisi}

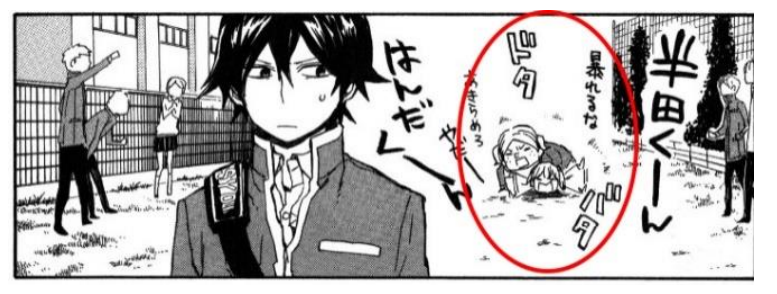

Gambar (3)

(3) ドタバタ

Dotabata

'Bak buk'

[Handa kun, 39, 2014, Jilid 1]

Dotabata merupakan gitaigo yang terdiri dari dua buah morfem, yaitu dota dan bata. Dota dan bata merupakan gitaigo dasar yang menjadi pembentuk dotabata sebagai sebuah gitaigo baru. Untuk mengetahui pembentukan gitaigo dotabata, dapat dilihat dari proses berikut.

$\begin{array}{ll}\begin{array}{l}\text { Stem } \\ \text { Dota } \\ \text { (Adv) }\end{array} & \begin{array}{l}\text { Mor.B } \\ \text { Bata } \\ \text { (Adv) }\end{array}\end{array} \quad \begin{aligned} & \text { Dotabata } \\ & \text { (Adv) }\end{aligned}$

Proses tersebut menjelaskan bahwa dota dan bata adalah dua buah morfem dasar berbeda yang kemudian digabungkan sehingga terjadi proses komposisi berupa native compound, yaitu proses pembentukan kata dengan cara menggabungkan dua buah kata asli bahasa Jepang sehingga menghasilkan gitaigo dotabata. Proses pembentukan ini terjadi secara inflektif karena tidak menimbulkan perubahan kelas kata. Dota dan bata memiliki kelas kata yang sama, yaitu adverbia sehingga menghasilkan sebuah adverbia dengan bentuk yang baru.

\subsection{Makna Gitaigo}

Dalam komik Handa Kun, unsur-unsur makna yang terkandung dalam gitaigo yang diterapkan tidak sama persis dengan asal gitaigo tersebut. Perbedaanperbedaan tersebut dapat berupa kuantitas tindakan/pergerakan, durasi terjadinya 
sesuatu, kondisi psikologis yang nampak atau tidak nampak, kesan positif/negatif, penyebab, tujuan, dan sebagainya.

\subsubsection{Makna Gitaigo yang Bereduplikasi}

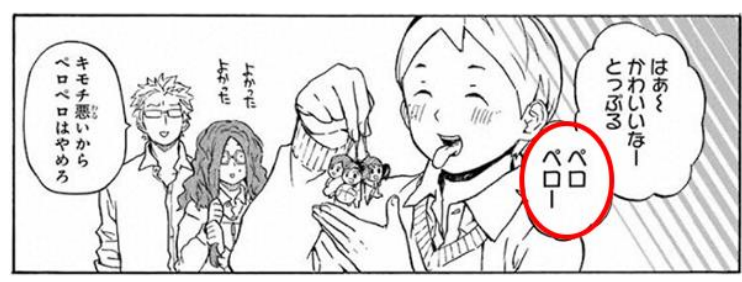

Gambar (1)

$\begin{array}{lll}\text { (1) はあー } & \text { かわいい } & \text { なー } \\ \text { Haaa } & \text { kawaii } & \text { naa } \\ \text { Aah } & \text { manis } & \text { SHU } \\ \text { とっぷる } & \text { ペロペロー } & \\ \text { toppuru } & \text { peroperoo } & \\ \text { triple } & \text { jilat-jilat } & \end{array}$

'Aah, triple yang manis, slerp slerp'

[Handa kun, 78, 2015, Jilid 3]

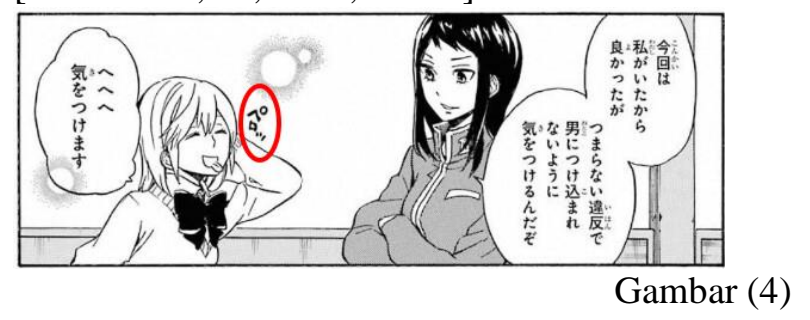

(4) ペロッ

Perott

'Te he'

[Handa kun, 5, 2015, Jilid 3]

Pada data (4), pero dituliskan dengan bentuk sokuon atau pemadatan suara untuk menunjukkan kesan gerakan yang cepat dan sesaat. Pada data (1), peropero dituliskan dengan penambahan vokal panjang atau choo'on yang digunakan untuk memberikan kesan aktivitas berlangsung lama. Unsur makna yang dimiliki gitaigo pero dan peropero, dapat dilihat pada tabel berikut.

Tabel (1) perbandingan komponen makna pero dan peropero.

\begin{tabular}{|l|c|c|}
\hline $\begin{array}{l}\text { KOMPONEN } \\
\text { MAKNA }\end{array}$ & Pero & Peropero \\
\hline 1. Mengeluarkan lidah & + & + \\
$\begin{array}{l}\text { 2. Memasukkan dan } \\
\text { mengeluarkan lidah } \\
\text { 3. Menjilat sesuatu }\end{array}$ & - & + \\
\hline
\end{tabular}




\begin{tabular}{|l|l|l|}
\hline $\begin{array}{l}\text { 4. Ungkapan ekspresi } \\
\text { tertawa konyol }\end{array}$ & + & - \\
\hline
\end{tabular}

Berdasarkan tabel tersebut, diketahui bahwa gitaigo pero dan peropero memiliki unsur turunan yang sama, yakni /mengeluarkan lidah/. Ketika pero bereduplikasi menjadi peropero, maka unsur tambahan yang muncul adalah /memasukkan dan mengeluarkan lidah/ dan /menjilat sesuatu/. Sebaliknya, unsur tambahan yang didapat dari data (4) untuk gitaigo pero adalah /ungkapan ekspresi tertawa konyol/. Gitaigo pero semata-mata hanya aktivitas mengeluarkan lidah dan terkadang disertai dengan ekspresi tertawa karena merasa diri konyol atau ceroboh, tidak terdapat niat untuk menjilat sesuatu. Sementara pada gitaigo peropero unsur makna /ungkapan ekspresi tertawa konyol/ tidak ada kerena peropero merupakan gerakan menjilat-jilat atau memasukkan dan mengeluarkan lidah, aktivitas ini tidak dapat disertai dengan aktivitas tertawa. Jadi, perubahan makna kata yang terjadi pada gitaigo peropero adalah perluasan makna. Selain itu, kedua gitaigo ini memiliki perbedaan dari segi tujuan penggunaannya. Pero hanya digunakan sebagai ekspresi tertawa ketika merasa konyol karena kecerobohan sendiri, sementara peropero digunakan sebagai ekspresi yang seakan ingin menjilat sesuatu atau benar-benar sedang menjilat-jilat sesuatu. Selain dari segi tujuan, perbedaan yang paling terlihat adalah dari segi kuantitas pergerakan. Pero hanya mengeluarkan lidah sebanyak satu kali, sementara peropero adalah melakukan gerakan memasukkan dan mengeluarkan lidah dengan cepat dan dapat dilakukan berkali-kali.

\subsubsection{Makna Gitaigo yang Berafiksasi}

Afiksasi yang ditemukan dalam komik Handa Kun seluruhnya berupa sufiks. Sufiks-sufiks yang ditemukan ada lima macam, yakni sufiks -suru, -saseru, -tsuku, -tsukeru, dan -ri (dapat dilihat di skripsi halaman 81-91). Berikut merupakan penjelasan makna gitaigo yang berafiksasi pada kata surari.

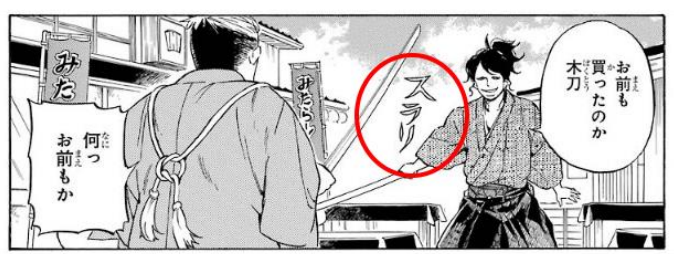


Gambar (2)

(2) スラリ

Surari

'Sret'

[Handa kun, 75, 2016, Jilid 5]

Surari merupakan gitaigo yang diberi imbuhan morfem $\{-r i\}$ sebagai sufiks penanda gitaigo yang berciri ringan, pelan, dan halus. Surari memiliki makna suatu kondisi fisik yang terlihat baik, yaitu ramping dan tinggi atau panjang. Selain itu juga memiliki makna pergerakan sebuah benda ramping yang digerakkan dengan mulus, misalnya pedang. Pada data (2), gitaigo surari diterapkan untuk menggambarkan sebuah pergerakan benda ramping yaitu pedang kayu yang diayunkan dengan ringan. Gitaigo sura sebagai pangkal dari surari juga memiliki beberapa unsur makna yang mirip. Untuk mengetahui komponen makna yang terdapat dalam gitaigo sura dan surari, dapat diperhatikan dalam tabel berikut.

Tabel (2) perbandingan komponen makna sura dan surari.

\begin{tabular}{|l|c|c|}
\hline KOMPONEN MAKNA & Sura & Surari \\
\hline 1. Ringan dan mudah & + & + \\
2. Ramping dan panjang & + & + \\
3. Kondisi fisik & + & + \\
4. Pergerakan & - & + \\
\hline
\end{tabular}

Gitaigo dasar sura dan surari memiliki komponen makna yang sebagian bersar mirip, yakni /ringan dan mudah/, /ramping dan panjang/, dan /kondisi fisik/. Hal ini dikarenakan gitaigo surari yang merupakan turunan dari gitaigo dasar sura sehingga komponen makna yang terkandung juga ikut diturunkan. Namun ketika mendapatkan imbuhan berupa morfem sufiks $\{-r i\}$ menjadi surari, terdapat unsur tambahan yang tidak dimiliki gitaigo sura, yakni menunjukkan suatu /pergerakan/. Gitaigo surari tidak hanya menggambarkan kondisi fisik benda yang ringan, mudah dibawa, ramping dan panjang, namun juga pergerakan benda tersebut. Morfem sufiks $\{-r i\}$ merupakan morfem yang khusus dilekatkan pada sebuah onomatope berciri ringan, pelan, dan halus, dalam hal ini adalah kondisi pergerakan suatu benda. Dapat disimpulkan bahwa perubahan makna kata yang terjadi pada gitaigo 
surari adalah perluasan makna. Hal ini dapat dilihat dari adanya unsur tambahan berupa pergerakan dan tidak hanya mengenai bentuk fisik suatu benda. Jadi, perbedaan yang terlihat antara gitaigo sura dan surari adalah dari ciri pergerakan yang disampaikan.

\subsubsection{Makna Gitaigo yang Berkomposisi}

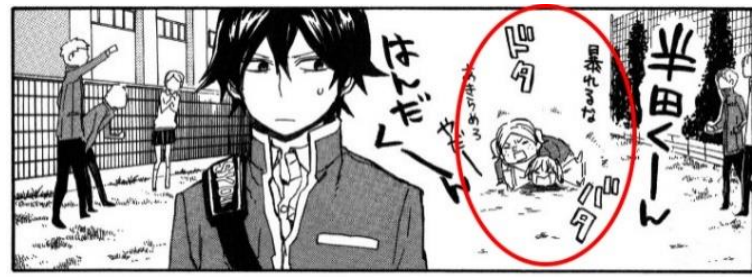

Gambar (3)

(3) ドタバタ

Dotabata

'Bak buk'

[Handa kun, 39, 2014, Jilid 1]

Pada data (3), gitaigo dotabata digunakan untuk menggambarkan situasi perkelahian sehingga menimbulkan suara bising yang tidak beraturan. Dotabata merupakan gitaigo yang telah berkomposisi antara dua kata, yaitu dari kata dota dan bata. Dota merupakan gitaigo yang digunakan untuk menggambarkan keadaan ribut karena suara langkah kaki yang berat, sementara bata digunakan dalam menggambarkan suara benda yang jatuh atau roboh. Unsur-unsur makna yang terdapat dalam gitaigo dota, bata, dan dotabata dapat dijabarkan dalam tabel komponen makna berikut.

Tabel (3) perbandingan komponen makna dota, bata dan dotabata.

\begin{tabular}{|l|c|c|c|}
\hline KOMPONEN MAKNA & Dota & Bata & Dotabata \\
\hline $\begin{array}{l}\text { 1. Suara bising atau ribut } \\
\text { 2. Sumber suara langkah } \\
\text { kaki }\end{array}$ & + & + & + \\
$\begin{array}{l}\text { 3. Sumber suara benda } \\
\text { jatuh atau roboh }\end{array}$ & - & + & + \\
$\begin{array}{l}\text { 4. Suara tidak beraturan } \\
\text { 5.Menggambarkan baku } \\
\text { hantam }\end{array}$ & - & - & + \\
\hline
\end{tabular}


Berdasarkan tabel (3) di atas, gitaigo dota, bata dan dotabata memiliki sebuah unsur turunan yang sama, yaitu /suara bising atau ribut/. Dalam gitaigo dota terdapat unsur makna /sumber suara langkah kaki/, sementara pada gitaigo bata terdapat unsur makna /sumber suara benda jatuh atau roboh/. Kemudian pada gitaigo hasil gabungan dari keduanya yaitu dotabata, unsur-unsur dari masingmasing gitaigo pembentuknya telah diturunkan. Selain itu, terdapat unsur makna tambahan berupa /suara tidak beraturan/ dan /menggambarkan baku hantam/. Pada data (3), suara yang dihasilkan dari dotabata adalah bersifat tidak beraturan karena tercipta dari dua sumber suara yang berbeda. Kemudian gitaigo dotabata juga digunakan untuk menggambarkan keadaan orang-orang yang sedang berkelahi, bukan hanya benda jatuh atau suara langkah kaki. Dapat disimpulkan bahwa perubahan makna kata yang terjadi pada gitaigo dotabata adalah perluasan makna. Hal ini karena terjadinya perpaduan sumber suara dan terbentuknya unsur makna baru dari penggabungan kata tersebut. Perbedaan yang paling terlihat pada ketiga gitaigo ini adalah selain dari penggunaannya juga dari segi sumber suara dan ketidakberaturan suara yang dihasilkan.

\section{Simpulan}

Berdasarkan analisis yang telah dilakukan, dapat ditarik beberapa kesimpulan mengenai pembentukan dan makna gitaigo dalam komik Handa Kun karya Satsuki Yoshino.

1) Keseluruhan data yang ditemukan dalam komik Handa Kun sejumlah 25 data gitaigo. Dari keseluruhan data, gitaigo bereduplikasi ditemukan 6 data, gitaigo berafiksasi ditemukan 5 data, gitaigo berkomposisi ditemukan 6 data, dan 7 data sisanya adalah data pendukung berupa bentuk dasar dari beberapa data tersebut yang digunakan dalam proses analisis pembentukan dan makna gitaigo dalam komik Handa Kun.

2) Dari keseluruhan data, 9 data gitaigo dalam komik Handa Kun terbentuk secara derivatif, sementara 8 data terbentuk secara inflektif. Sisanya tidak terjadi pembentukan karena merupakan pangkal dari proses pembentukan 
tersebut. Sebagian besar gitaigo dibentuk dengan proses pengulangan morfem sebelum diberi imbuhan atau digabungkan dengan morfem lain.

3) Seluruh data gitaigo yang dianalisis pasti memiliki unsur makna turunan dari gitaigo pangkalnya. Melalui analisis komponen makna, ditemukan perubahan makna kata yang meluas terjadi pada 11 data gitaigo, yakni guigui, peropero, surasura, iraira saseru, surari, mukatsuku, niyaniyashiya, kirakiraguzzu, dotabata, shikkarimono, dan dokadosu. Kemudian perubahan makna kata yang menyempit terjadi pada 6 data gitaigo, yakni boroboro, keshikeshi, dokidoki, nurunuru suru, urotsukeru, dan characharao.

4) Unsur tambahan pada data-data gitaigo yang bereduplikasi sebagian besar adalah/gerakan berulang/ dan /berkesinambungan/. Sementara pada gitaigo yang berafiksasi dan berkomposisi terdapat unsur tambahan yang variatif, sebagian besar dari aspek psikologis, penerapan (sebagai penanda pergerakan dan karakter), dan kesan yang dihasilkan. Namun pada gitaigo yang berkomposisi dengan sesama gitaigo terdapat unsur tambahan khusus berupa /ketidakberaturan/ dan /perpaduan sumber suara/.

\section{Daftar Pustaka}

Akimoto, Miharu. 2002. Yoku Wakaru Goi. Tokyo: ALC.

Arisuta. 2017. "Strategi Penerjemahan dan Pergeseran Makna Onomatope pada Lirik Lagu JKT48” (Skripsi). Denpasar: Universitas Udayana.

Ba'dulu, Abdul Muis dan Herman. 2010. Morfosintaksis. Jakarta: PT RINEKA CIPTA.

Chaer, Abdul. 2015a. Linguistik Umum. Jakarta: Rineka Cipta.

Chaer, Abdul. 2015b. Morfologi Bahasa Indonesia (Pendekatan Proses). Jakarta: PT RINEKA CIPTA.

Dahidi, A. dan Sudjianto. 2012. Pengantar Linguistik Bahasa Jepang. Jakarta: Kesaint Blanc. 
Erdika. 2016. "Gijougo dalam Manga Great Teacher Onizuka Karya Toru Fujisawa” (Skripsi). Denpasar: Universitas Udayana.

Firmanningrum. 2016. "Komponen Makna Kata Kerja yang Bermakna 'Memukul' dalam Bahasa Jawa" (Skripsi). Yogyakarta: Universitas Sanata Dharma.

Fukuda, Hiroko. 2017. Onomatope dalam Bahasa Jepang. Jakarta: Kesaint Blanc.

Mahsun. 2005. Metode Penelitian Bahasa. Jakarta: PT Rajagrafindo Persada.

Manga, Raw. 2008. Handa Kun Manga 1-7:http://jpraws.net/handa-kun-v1-2ongoing/ (Diunduh 26 Mei 2018).

Panduwinata, O Lydia. 2013. "Variasi Makna dan Penerapan Onomatope dalam Komik Bakuretsu Utahime 21 Karya Igarashi Kaoru”, Jurnal Japanology, Vol. 1, No. $\quad 2, \quad$ pp $1-15$.

Sudaryanto. 1993. Metode dan Aneka Teknik Analisis Bahasa. Yogyakarta: Duta Wacana University Press.

Tsujimura, Natsuko. 1996. An Introduction Japanese Linguistics. UK: Blackwell Publishing.

Yoshino, Satsuki. 2017. Handa Kun. Jakarta: PT Elex Media Komputindo. 